\title{
An upgraded comprehensive multilocus phylogeny of the Tardigrada tree of life
}

Guil, Noemi; Jørgensen, Aslak; Kristensen, Reinhardt

Published in:

Zoologica Scripta

DOI:

$10.1111 /$ zsc. 12321

Publication date:

2019

Document version

Publisher's PDF, also known as Version of record

Document license:

CC BY

Citation for published version (APA):

Guil, N., Jørgensen, A., \& Kristensen, R. (2019). An upgraded comprehensive multilocus phylogeny of the Tardigrada tree of life. Zoologica Scripta, 48(1), 120-137. https://doi.org/10.1111/zsc.12321 


\title{
An upgraded comprehensive multilocus phylogeny of the Tardigrada tree of life
}

\author{
Noemi Guil $^{1}$ (D) | Aslak Jørgensen ${ }^{2} \quad$ Reinhardt Kristensen ${ }^{3}$
}

${ }^{1}$ Department of Biodiversity and Evolutionary Biology, Museo Nacional de Ciencias Naturales (MNCN-CSIC), Madrid, Spain

${ }^{2}$ Department of Biology, University of Copenhagen, Copenhagen, Denmark

${ }^{3}$ Zoological Museum, Natural History Museum of Denmark, University of Copenhagen, Copenhagen, Denmark

\section{Correspondence}

Noemi Guil, Department of Biodiversity and Evolutionary Biology, Museo Nacional de Ciencias Naturales (MNCN-CSIC), Madrid, Spain.

Email: nguillopez@gmail.com

\section{Funding information}

JAE-DOC Program, Grant/Award Number: JAE-DOC 2009-2012; European Marie Curie, Grant/Award Number: FP7-PEOPLE-2010-RG and PERG07GA-2010-268289 ; Consejo Superior de Investigaciones Científicas; FP7

\begin{abstract}
Providing accurate animals' phylogenies rely on increasing knowledge of neglected phyla. Tardigrada diversity evaluated in broad phylogenies (among phyla) is biased towards eutardigrades. A comprehensive phylogeny is demanded to establish the representative diversity and propose a more natural classification of the phylum. So, we have performed multilocus (18S rRNA and 28S rRNA) phylogenies with Bayesian inference and maximum likelihood. We propose the creation of a new class within Tardigrada, erecting the order Apochela (Eutardigrada) as a new Tardigrada class, named Apotardigrada comb. n. Two groups of evidence support its creation: (a) morphological, presence of cephalic appendages, unique morphology for claws (separated branches) and wide-elongated buccopharyngeal apparatus without placoids, and (b) phylogenetic support based on molecular data. Consequently, order Parachela is suppressed and its superfamilies erected as orders within Eutardigrada, maintaining their current names. We propose a new classification within the family Echiniscidae (Echiniscoidea, Heterotardigrada) with morphological and phylogenetic support: (a) subfamily Echiniscinae subfam. n., with two tribes Echiniscini tribe n. and Bryodelphaxini tribe n.; (b) subfamily Pseudechiniscinae subfam. n., with three tribes Cornechiniscini tribe n., Pseudechiniscini tribe n. and Anthechiniscini tribe n.; and (c) subfamily Parechiniscinae subfam. n., with two tribes Parechiniscini tribe $\mathrm{n}$. and Novechiniscini tribe $\mathrm{n}$. Reliable biodiversity selection for tardigrades in broad phylogenies is proposed due to biased analyses performed up to now. We use our comprehensive molecular phylogeny to evaluate the evolution of claws in the clawless genus Apodibius and claw reduction across the Tardigrada tree of life. Evolutionary consequences are discussed.
\end{abstract}

\section{K E Y W O R D S}

classification, clawless evolution, molecular phylogeny, new class, new heterotardigrade subfamilies, Tardigrada

\section{1 | INTRODUCTION}

Animals' phylogenies, our understanding of their evolution and implications in our scheme of relationships within the tree of life have increased in the latest decades, due to vast advances in molecular information for phylogenetic studies.
On the one hand, exploration of new genetic information has opened the possibility to solve several uncertainties within the tree of life at different node levels (Boeckmann et al., 2015; Burki, 2014; Giribet, 2016a). On the other hand, the inclusion of new organisms' diversity in selected phyla has returned in novel hypothesis hardly considered before the molecular 
era (Aguinaldo et al., 1997; Dunn, Giribet, Edgecombe, \& Hejnol, 2014; Giribet, 2016a, 2016b). However, uncertainties do still prevail specially regarding small invertebrates, probably caused by low and/or unappropriate diversity included (Guil \& Giribet, 2012). Improvements within phylogenies of neglected phyla will help in inclusion of appropriate representation of internal diversity for each phylum (see Discussions, e.g., in Rokas, Kruger, \& Carroll, 2005; Roeding et al., 2007; Dunn et al., 2008; Hejnol et al., 2009; Pick et al., 2010; Giribet, 2016a).

Among those neglected phyla is Tardigrada. Tardigrades comprise ca. 1,200 species (Degma, Bertolani, \& Guidetti, 2018) that inhabit terrestrial, freshwater and marine environments in all altitudes and latitudes, from the North Pole to the South Pole, and from the highest peaks to the deepest ocean trenches (Nelson, Guidetti, \& Rebecchi, 2015). Three classes organize the phylum classification: Heterotardigrada with ca. $41 \%$ of tardigrade diversity, Eutardigrada with ca. $59 \%$ of total diversity and Mesotardigrada, a monospecific class which validity has been repeatedly questioned (Grothman et al., 2017; Ramazzotti \& Maucci, 1983). The most remarkable characteristic of tardigrades is their ability to survive under extreme terrestrial and extraterrestrial conditions (Guidetti, Altiero, \& Rebecchi, 2011; Jönsson, Rabbow, Schill, Harms-Ringdahl, \& Rettberg, 2008; Møbjerg et al., 2011; Persson et al., 2011; Rebecchi et al., 2009). Their biological and physical characteristics (dispersal and cryptobiotic capabilities, physiological mechanisms, resistance of cuticle for new materials) bestowed a model organism in several fields on them (such as the use of substances and mechanisms involved in their cryptobiosis in Biomedicine; their survival in extreme conditions searching for life in other planets; and solving evolutionary questions; see, e.g., Erdmann \& Kaczmarek, 2017; Guil, 2011; Horikawa et al., 2008; Hashimoto et al., 2016). In spite of those potential uses, fundamental questions about tardigrades, such as internal phylogenetic relationships, are still hardly understood. The phylum has been included within the superphylum Ecdysozoa, closely related to arthropods and onychophorans in the majority of more recent molecular phylogenies (Dunn et al., 2014, 2008 ; Hejnol et al., 2009), although heterotardigrades are poorly represented on those phylogenies (Guil \& Giribet, 2012). Both analysed classes (Heterotardigrada and Eutardigrada) have been supported in many studies (Bertolani et al., 2014; Garey, Nelson, Mackey, \& Li, 1999; Marley, McInnes, \& Chester, 2011; Sands et al., 2008), even though class monophyly has been proven to be outgroup dependent (Guil \& Giribet, 2012). In addition, modifications towards a natural classification of tardigrades have been proposed based on molecular phylogenies (Bertolani et al., 2014; Dabert, Dastych, Hohberg, \& Dabert, 2014; Guil \& Giribet, 2012; Guil, Machordom, \& Guidetti, 2013; Marley et al., 2011; Sands et al., 2008).
The main objective of this study is better understanding internal relationship within the Tardigrada phylogeny through a more comprehensive analysis. Secondary objectives will be: (a) evaluate monophyletic status from orders to genera considering classification changes, if needed; (b) provide tardigrade taxa selection for future metazoans' phylogenies; and (c) infer evolutionary traces of claws in the clawless genus Apodibius and claw reduction by means of the upgraded Tardigrada phylogeny.

\section{2 | MATERIAL AND METHODS}

\section{1 | Specimens' collection and identifications}

Specimens for this study were obtained from Reinhardt M. Kristensen collection of mosses and lichens housed in the Natural History Museum of Denmark (University of Copenhagen), and Noemi Guil collection of mosses and lichens deposited at the National Museum of Natural History in Madrid (CSIC, Spain), where voucher samples are deposited. Dry moss samples were soaked in water overnight, washed, squeezed and filtered through a 32- $\mu \mathrm{m}$ mesh-size sieve. The filtered product was transferred to a Petri dish for examination under a stereomicroscope. Each specimen was then isolated, and mounted in temporary microscopy slides with distilled water, and identified by light microscopy at the highest possible magnification $(100 \times$ objective $)$ using phase contrast and following current taxonomic standards and specific keys (Bertolani et al., 2014; Cesari et al., 2016; Degma et al., 2018; Fontoura \& Pilato, 2007; Guidetti \& Bertolani, 2005; Guidetti et al., 2016; Guidetti, Schill, Bertolani, Dandekar, \& Wolf, 2009; Kaczmarek \& Michalczyk, 2017; Kaczmarek, Gawlak, Bartels, Nelson, \& Roszkowska, 2017; Kaczmarek, Goldyn, Prokop, \& Michalczyck, 2011; Marley et al., 2018, 2011 ; Michalczyck, Welnicz, Frohme, \& Kaczmarek, 2012; Michalczyk \& Kaczmarek, 2005, 2010; Tumanov, 2006; Vecchi et al., 2016). In addition, taxonomically relevant structures (cuticle, claws, buccopharyngeal apparatus, eggs when available, etc.; Ramazzotti \& Maucci, 1983; Guidetti \& Bertolani, 2005; Pilato \& Binda, 2010) for each specimen were photographed, recorded and stored.

\section{2 | Molecular analyses}

Two nuclear ribosomal genes 18S rRNA and 28S rRNA were chosen because they have been proven informative for tardigrade phylogenies in previous analyses (Bertolani et al., 2014; Cesari et al., 2016; Dabert et al., 2014; Guidetti et al., 2016; Guil \& Giribet, 2012; Jørgensen, Møbjerg, \& Kristensen, 2011; Marley et al., 2011; Sands et al., 2008; Vecchi et al., 2016). DNA was extracted from 45 individuals 
TA B L E 1 List of species and specimens newly sequenced for this study

\begin{tabular}{|c|c|c|c|c|c|c|c|}
\hline Locality & & & $\begin{array}{l}\text { Collection } \\
\text { Year }\end{array}$ & Species & Code & \multicolumn{2}{|c|}{ Genbank accession number } \\
\hline \multirow{8}{*}{$\begin{array}{l}\text { Arctic Station, Disko } \\
\text { Island, Greenland }\end{array}$} & \multirow[t]{8}{*}{$\mathrm{N} 69^{\circ} 19^{\prime}$} & \multirow[t]{8}{*}{ W $54^{\circ} 04^{\prime}$} & 2004 & Dactylobiotus ambiguus & TarCPH_7 & & MH079500 \\
\hline & & & 2004 & Diaforobiotus islandicus & TarCPH_23 & & MH079486 \\
\hline & & & 2004 & Hypsibius cf. dujardini & TarCPH_13 & & МH079506 \\
\hline & & & 2004 & Macrobiotus echinogenitus & TarCPH_16 & MH079460 & MH079513 \\
\hline & & & 2004 & Mesobiotus harmsworthi & TarCPH_18 & MH079462 & МH079489 \\
\hline & & & 2004 & Murrayon pullari & TarCPH_29 & & МH079499 \\
\hline & & & 2009 & Milnesium cf. tardigradum & TarCPH_27 & MH079453 & МH079477 \\
\hline & & & 2009 & Milnesium cf. tardigradum & Tar758 & MH079455 & MH079478 \\
\hline $\begin{array}{l}\text { Eysturoy, Faroe } \\
\text { Islands }\end{array}$ & $\mathrm{N} 62^{\circ} 16^{\prime}$ & $\mathrm{W} 07^{\circ} 00^{\prime}$ & 2003 & Austeruseus faeroensis & TarCPH_4 & MH079470 & МH079481 \\
\hline Godhavn, Greenland & $\mathrm{N} 69^{\circ} 14^{\prime}$ & W $53^{\circ} 32^{\prime}$ & 2004 & Ramazzottius cataphractus & TarCPH_30 & & MH079508 \\
\hline Helsingør, Denmark & $\mathrm{N} 56^{\circ} 02^{\prime}$ & E $12^{\circ} 36^{\prime}$ & 2009 & Halobiotus crispae & Tar789 & & MH079516 \\
\hline $\begin{array}{l}\text { Ikka Fjord, South } \\
\text { Greenland }\end{array}$ & $\mathrm{N} 61^{\circ} 12^{\prime}$ & $\mathrm{W} 48^{\circ} 00^{\prime}$ & 2007 & Bertolanius weglarskae & TarCPH_1 & МH079469 & \\
\hline \multirow[t]{3}{*}{ Ivittuut, Greenland } & \multirow[t]{3}{*}{$\mathrm{N} 61^{\circ} 12^{\prime}$} & \multirow[t]{3}{*}{$\mathrm{W} 48^{\circ} 10^{\prime}$} & 2007 & Adorybiotus granulatus & $\operatorname{Tar} 720$ & MH079463 & MH079494 \\
\hline & & & 2007 & Adorybiotus granulatus & Tar721 & MH079464 & MH079495 \\
\hline & & & 2007 & Adorybiotus granulatus & $\operatorname{Tar} 722$ & MH079465 & МH079496 \\
\hline \multirow{3}{*}{$\begin{array}{l}\text { Milodon Cave, } \\
\text { Patagonia, Chile }\end{array}$} & \multirow[t]{3}{*}{$\mathrm{S} 51^{\circ} 34^{\prime}$} & \multirow[t]{3}{*}{$\mathrm{W} 72^{\circ} 37^{\prime}$} & 2004 & Macrobiotus hufelandi & TarCPH_19 & & MH079484 \\
\hline & & & 2004 & Mesobiotus liviae & TarCPH_24 & & MH079488 \\
\hline & & & 2003 & Macrobiotus furcatus & TarCPH_28 & MH079468 & MH079492 \\
\hline \multirow[t]{2}{*}{ Nivå, Denmark } & \multirow[t]{2}{*}{ N 55 $56^{\prime}$} & \multirow[t]{2}{*}{ E $12^{\circ} 30^{\prime}$} & 2004 & Isohypsibius prosostomus & TarCPH_14 & & MH079509 \\
\hline & & & 2004 & Macrobiotus hufelandi & TarCPH_21 & & MH079487 \\
\hline Øland, Sweden & N $56^{\circ} 44^{\prime}$ & E $16^{\circ} 40^{\prime}$ & 2004 & Ramazzottius oberhaeuseri & TarCPH_31 & MH079474 & MH079507 \\
\hline $\begin{array}{l}\text { Østerlien, Disko } \\
\text { Island, Greenland }\end{array}$ & $\mathrm{N} 69^{\circ} 15^{\prime}$ & $\mathrm{W} 53^{\circ} 31^{\prime}$ & 2009 & Milnesium cf. tardigradum & Tar763 & & МH079479 \\
\hline \multirow{8}{*}{$\begin{array}{l}\text { Røen Sø, Disko } \\
\text { Island, Greenland }\end{array}$} & \multirow[t]{8}{*}{$\mathrm{N} 69^{\circ} 15^{\prime}$} & \multirow[t]{8}{*}{$\mathrm{W} 53^{\circ} 31^{\prime}$} & 2004 & Adropion prorsirostre & TarCPH_10 & & MH079514 \\
\hline & & & 2004 & Astatumen trinacriae & TarCPH_5 & & MH079515 \\
\hline & & & 2005 & Calohypsibius ornatus & Tar778 & & MH079502 \\
\hline & & & 2005 & Calohypsibius ornatus & $\operatorname{Tar} 779$ & & MH079503 \\
\hline & & & 2005 & Calohypsibius ornatus & Tar795 & MH079472 & MH079504 \\
\hline & & & 2005 & Calohypsibius ornatus & Tar801 & MH079471 & MH079505 \\
\hline & & & 2004 & Disphascon pingue & TarCPH_9 & MH079473 & \\
\hline & & & 2004 & Macrobiotus hufelandi & TarCPH_20 & & МH079485 \\
\hline
\end{tabular}


T A B L E 1 (Continued)

\begin{tabular}{|c|c|c|c|c|c|c|c|}
\hline \multirow[b]{2}{*}{ Locality } & & & \multirow{2}{*}{\multicolumn{2}{|c|}{$\begin{array}{l}\text { Collection } \\
\text { Year }\end{array}$}} & \multirow[b]{2}{*}{ Code } & \multicolumn{2}{|c|}{ Genbank accession number } \\
\hline & \multicolumn{2}{|c|}{ Coordinates } & & & & 18S rRNA & 28S rRNA \\
\hline Svaneke, Denmark & $\mathrm{N} 55^{\circ} 08^{\prime}$ & E $15^{\circ} 08^{\prime}$ & 2004 & Astatumen trinacriae & TarCPH_6 & & MH079501 \\
\hline Vellerup, Denmark & N $55^{\circ} 14^{\prime}$ & E $11^{\circ} 51^{\prime}$ & 2005 & Halobiotus crispae & TarCPH_12 & & MH079510 \\
\hline $\begin{array}{l}\text { Wombeyan caves, } \\
\text { Australia }\end{array}$ & $\mathrm{S} 34^{\circ} 19^{\prime}$ & E $149^{\circ} 59^{\prime}$ & 1996 & $\begin{array}{l}\text { Doryphoribius zyxiglobus } \\
\text { Doryphoribius zyxiglobus }\end{array}$ & $\begin{array}{l}\text { Tar787 } \\
\text { Tar788 }\end{array}$ & MH079475 & MH079483 \\
\hline $\begin{array}{l}\text { Zackenberg, } \\
\text { Sydkæret, }\end{array}$ & $\mathrm{N} 74^{\circ} 30^{\prime}$ & $\mathrm{W} 20^{\circ} 30^{\prime}$ & 2004 & Macrobiotus sp. & TarCPH_22 & & МH079491 \\
\hline Greenland & & & 2004 & Doryphoribius macrodon & TarCPH_11 & & MH079482 \\
\hline
\end{tabular}

Note. Localities, coordinates, year of collection, species, code in analyses and Genbank accession numbers for each individual and gene are specified.

${ }^{\mathrm{a}}$ Sequences obtained from an embryonated egg.

(Table 1) with the DNeasy Tissue Kit (Qiagen) following the manufacturer's protocol (including the 10-min incubation at $72^{\circ} \mathrm{C}$ after adding Buffer AL, currently deleted from manufacturer protocol), and re-suspended in $100 \mu \mathrm{l}$ of $\mathrm{ddH}_{2} \mathrm{O}$, as described by Guil and Giribet (2009).

A fragment from the nuclear ribosomal 18S rRNA (663-706 bp depending on the species), which showed most of the genetic variation in previous tardigrades analyses, was amplified using the universal primer pair $18 \mathrm{~S}$ a2.0 (5'-ATG GTT GCA AAG CTG AAA C-3'; Whiting, Carpenter, Wheeler, \& Wheeler, 1997) and 18S 9R (5'-GAT CCT TCC GCA GGT TCA CCT AC-3'; Giribet, Carranza, Baguña, Riutort, \& Ribera, 1996). Amplifications were performed in a $22 \mu \mathrm{l}$ volume of a solution containing $14 \mu \mathrm{l}$ of $\mathrm{ddH}_{2} \mathrm{O}, 1 \mu \mathrm{l}$ of $10 \times$ polymerase chain reaction buffer, $2 \mu \mathrm{l}$ of dNTP's mix (10 mM), $1.0 \mu$ of each primer $(100 \mu \mathrm{M})$, $0.1 \mu \mathrm{l}$ of AmpliTaq $^{\circledR}$ DNA polymerase (Applied Biosystems) and $3.0 \mu \mathrm{l}$ of DNA template. The PCR protocol developed to amplify the $18 \mathrm{~S}$ rRNA fragments consisted of an initial denaturing step at $94^{\circ} \mathrm{C}$ for $5 \mathrm{~min}, 35$ amplification cycles $\left(94^{\circ} \mathrm{C}\right.$ for $10 \mathrm{~s}, 42-45^{\circ} \mathrm{C}$-depending on taxon-for $30 \mathrm{~s}$ and $72^{\circ} \mathrm{C}$ for $30 \mathrm{~s}$ ), a final elongation step of $7 \mathrm{~min}$ at $72^{\circ} \mathrm{C}$, and a rapid thermal ramp to $4^{\circ} \mathrm{C}$. A fragment of the nuclear ribosomal $28 \mathrm{~S}$ rRNA $(1,344-1,446$ bp depending on the species) was amplified using the pair of universal primers: 28Sa (5'-GAC CCG TCT TGA AAC ACG GA-3'; Whiting et al., 1997) and 28Srd5b (5'-CCA CAG CGC CAG TTC TGC TTAC-3'; Schwendinger \& Giribet, 2005). Amplifications were performed as for 18S rRNA. All PCR products were checked for the presence of amplicons of the expected size on a $1.0 \%$ agarose gel electrophoresis. PCR products were purified with the QIAquick PCR Purification Kit (Qiagen) using the manufacturer's protocols. Fragments successfully sequenced for each taxon and specimen are shown in Table 1.

Cycle sequencing with AmpliTaq DNA polymerase was as described by Guil and Giribet (2012). Cycle-sequenced products were cleaned using a standard protocol with ethanol, sodium acetate and formamide. The BigDye ${ }^{\circledR}$-labelled products were directly sequenced using an automated ABI PRISM 310 Genetic Analyzer. Chromatograms obtained from the sequencer were read, and contigs assembled using the sequence editing software SEQUENCHER version 4.1.4 (Gene Codes Corporation, Ann Arbor, MI). Assembled sequences were edited with BioEdit version 2007 (Hall, 1999), to identify fragments based on internal primers and conserved regions, as in a previous work (Guil \& Giribet, 2012). All new sequences have been deposited in GenBank under accession numbers MH079453 to MH079475 for 18S rRNA, and MH079494 to MH079516 for 28S rRNA (Tables 1 and Supporting information Table S1).

\section{3 | Phylogenetic analyses}

We used available tardigrade sequences in GenBank, coincident with fragments analysed in the present study (Supporting information Table S1), to perform a more comprehensive analysis. We used four outgroups as in Guil and Giribet (2012) (Table 2). Disparity of genetic markers used for phylogenetic analyses of the Tardigrada phylum and taxa with those markers made us to perform three parallel analyses with: (a) $18 \mathrm{~S}$ rRNA (fragment delimited by primers $18 \mathrm{~S}$ a2.0 and $18 \mathrm{~S} 9 \mathrm{R}$ ), (b) $28 \mathrm{~S}$ rRNA (fragment delimited by primers 28Sa and 28S 5b) and (c) a combined analysis with specimens where both genes, $18 \mathrm{~S}$ and $28 \mathrm{~S}$, were successfully sequenced (Table 1).

Parallel analyses of maximum likelihood (ML) and Bayesian analyses (BI) were performed. Prior to likelihood analysis, jModeltest 2.1.1 (Darriba, Taboada, Doallo, \& Posada, 2012) was executed to choose the best-fit model of nucleotide substitution for each gene (18S and 28S) and combined matrices, under the Akaike information criterion (AIC). For the $18 \mathrm{~S}$ data set, the model $012343+\mathrm{I}+\mathrm{G}+\mathrm{F}$ was obtained (with corrections for gamma distributions, proportion of invariable unchanging sites and the equilibrium base frequencies in the sequences are estimated by observing the occurrence in the data). For $28 \mathrm{~S}$, the model TIM2+I+G (transition model) 


\begin{tabular}{|c|c|c|c|}
\hline \multirow[b]{2}{*}{ Taxa } & \multirow[b]{2}{*}{ Species } & \multicolumn{2}{|l|}{ Genes } \\
\hline & & $18 S$ a2.0-9R & $28 S a-5 b$ \\
\hline \multicolumn{4}{|c|}{ Arthropoda } \\
\hline \multicolumn{4}{|c|}{ Mandibulata } \\
\hline \multicolumn{4}{|c|}{ Pancrustacea } \\
\hline & Allacma fusca & EU368610 & EU376054 \\
\hline \multicolumn{4}{|c|}{ Myriapoda } \\
\hline & Dendrothereua homa & FJ660705 & FJ660746 \\
\hline \multicolumn{4}{|c|}{ Arthropoda } \\
\hline \multicolumn{4}{|c|}{ Chelicerata } \\
\hline \multicolumn{4}{|c|}{ Xyphosura } \\
\hline & Limulus polyphemus & M20083 & M20084 \\
\hline \multicolumn{4}{|c|}{ Priapulida } \\
\hline & Priapulus caudatus & AF025927 & AY210840 \\
\hline
\end{tabular}

TA B LE 2 Genbank accession numbers for outgroups used in analyses was resulted (with corrections for gamma distributions and proportion of invariable unchanging sites). Combined analyses were performed with partition data and their respective model described for each one. ML analyses were conducted using the program IQ-Tree (Nguyen, Schmidt, Haeseler, \& Minh, 2015) in the web server version (https://iqtree.cibiv.univie.ac.at/), adapting model obtained with jModeltest. Nodal support was evaluated with 100 bootstrap replicates.

BI was performed with MrBayes version 3.1.2 (Huelsenbeck \& Ronquist, 2001; Ronquist \& Huelsenbeck, 2003). Substitution model was specified in each case with parameters specifications as obtained with MrModeltest (Nylander, 2004) and separated models configured in combined analyses. Burn-in times were assessed by first running shorter analyses and graphing the Bayesian log likelihoods (LnL); these burnin times were subsequently confirmed by comparison with the complete log likelihood graphs of all analyses after 15,000,000 generations. Using Tracer version 1.5, burn-in times in a log likelihood graphs of all analyses were visualized, discarding 50,000 trees in each analysis. Support for nodes is expressed as posterior probabilities, calculated on a maximum clade credibility tree of the post-burn-in sample.

\section{\begin{tabular}{l|l}
3 & RESULTS
\end{tabular}}

We have sequenced 45 specimens from 26 taxa, obtained from moss and lichen samples collected in 18 localities widely distributed (Table 1 and Supporting information Table S1). This study included a large tardigrade diversity, as it covered over $80 \%$ of tardigrade families and subfamilies and $53 \%$ of genera (Table 3), making relevant conclusions achieved. Sequenced eutardigrade species represent all eutardigrade superfamilies, $92 \%$ of families and 59\% genera (Table 3 and Supporting information Table S1). Seven species and one genus (Austeruseus; Trygvadóttir \& Kristensen, 2001) were newly sequenced for these molecular analyses (Table 1 and Supporting information Table S1).

ML and BI analyses have been congruent between them irrespective genes used, being BI support stronger than ML bootstraps (Figures 1-3 for 18S; Figures 4,5 for 28S). Analyses combining $18 \mathrm{~S}$ and $28 \mathrm{~S}$ complete data sets agreed with analyses including one gene (18S or 28S) (Figure 6). Information from the 18S rRNA solved nodes at different levels within the phylogeny (from classes to genera), while 28S rRNA solved deep (classes) and terminal nodes (genera and groups of genera) but not middle nodes. The two classes (Heterotardigrada and Eutardigrada) were supported with $18 \mathrm{~S}, 28 \mathrm{~S}$ and combined phylogenies, as well as eutardigrade orders Apochela and Parachela (Figures 1-6). Within Heterotardigrada, only family

T A B L E 3 Diversity of genera, subfamilies, families and superfamilies analysed are presented globally and by class (Heterotardigrada and Eutardigrada) in absolute numbers; percentages were included respect total diversity within Tardigrada, following Degma et al. (2018) and more recent taxonomic changes (Cesari et al., 2016; Guidetti et al., 2016; Vecchi et al., 2016)

\begin{tabular}{|lccc|}
\hline Taxa level & Total & Heterotardigrada & Eutardigrada \\
\hline Absolute numbers & & & \\
\hline Genera & 63 & 27 & 36 \\
\hline Subfamilies & 13 & 8 & 5 \\
\hline Families & 17 & 6 & 11 \\
\hline Superfamilies & 4 & 0 & 4 \\
\hline Percentage respect & global tardigrade diversity & \\
\hline Genera & 53 & 47 & 59 \\
\hline Subfamilies & 81 & 73 & 100 \\
\hline Families & 85 & 50 & 92 \\
\hline Superfamilies & 100 & 0 & 100 \\
\hline
\end{tabular}


Echiniscidae was supported by the three analyses (18S, 28S and combined), and order Echiniscoidea was only recovered with combined analysis (Figures 1-6). Families Halechiniscidae, Echiniscoididae and Echiniscidae were monophyletic. The family Echiniscidae was divided into five phylogenetic lineages despite the data used: (a) Hypechiniscus, Testechiniscus, Diploechiniscus and Echiniscus; (b) Bryodelphax and Bryochoerus; (c) Acanthechiniscus, Antechiniscus, Cornechiniscus and Proechiniscus; (d) Pseudechiniscus (P. novaezeelandiae, P. faccettlais and P. suillus); and (e) Parechiniscus (Figures 1, 4 and 6). Mopsechiniscus remained in a doubtful position within the family Echiniscidae.
The family Milnesiidae (Apochela, Eutardigrada) showed two phyletic lines (Figure 6): (a) Milnesium eurystomum (Spain) with Milnesium tardigradum from Denmark, Greenland and Spain, and (b) Milnesium tardigradum from Spain. Within parachelans, four phylogenetic lineages corresponding to superfamilies were supported (by $18 \mathrm{~S}$ rRNA and combined analyses; Figures 2, 3 and 6): Hypsibioidea, Eohypsibioidea, Macrobiotoidea and Isohypsibioidea. At the level of parachelan superfamilies and families, $28 \mathrm{~S}$ rRNA information showed no resolution (Figure 5). The family Eohypsibiidae confirmed its monophyly incorporating a new genus, Austeruseus (Figures 3, 5 and 6). Within

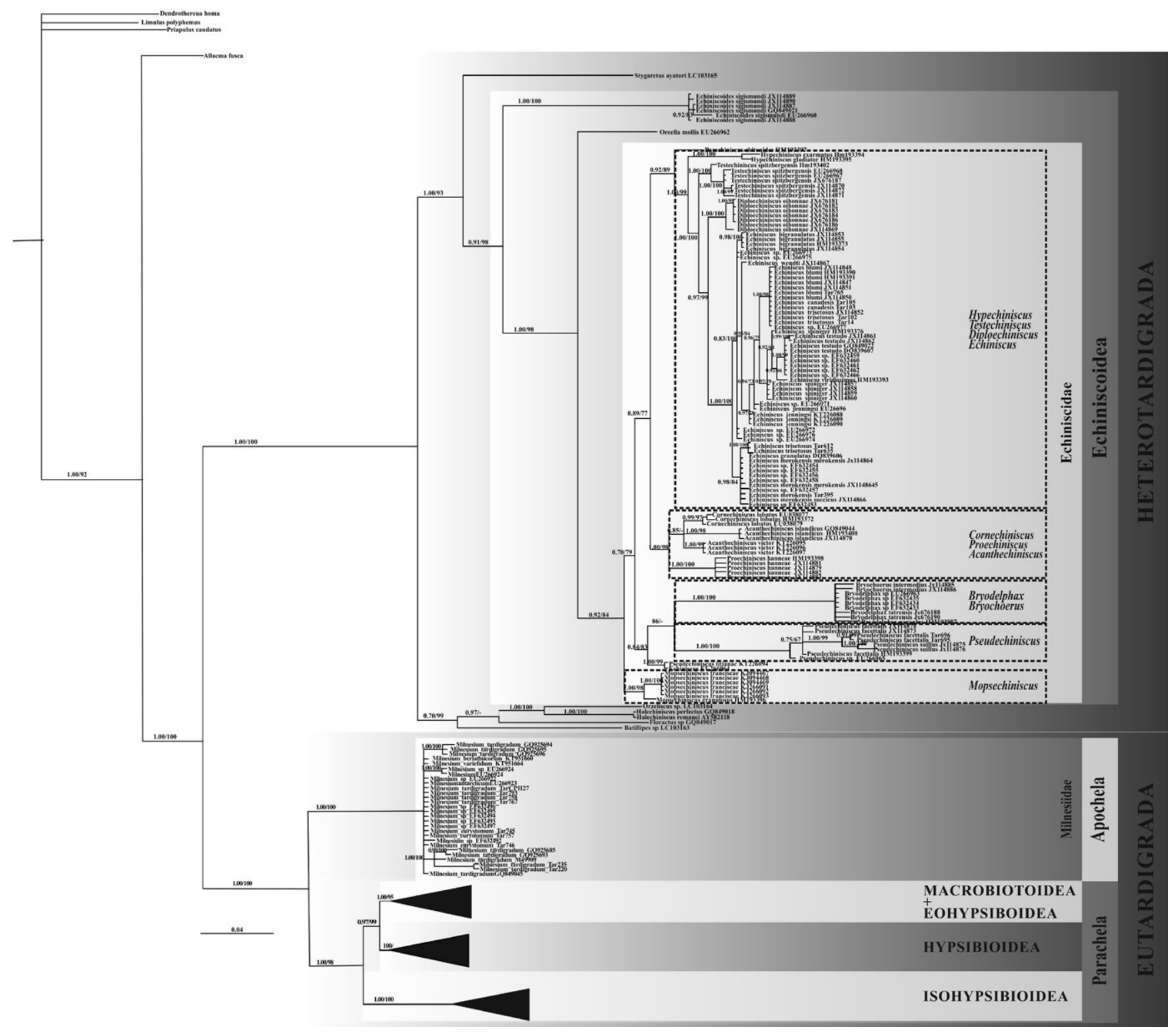

F I G U RE 1 Bayesian phylogram obtained with the nuclear 18S a2.0-9R data set (Supporting information Table S1). First number above branches is posterior probabilities obtained in the BI. Second number is bootstrap support values from ML. Taxa are named following Supporting information Table S1. Parachelan superfamilies are represented in detail in Figures 2-3. Classes, orders, families, superfamilies, genus and group of genera are indicated. Squares in different grey scales and dot limited squares highlight supported clades at different node levels. Scale bar $=$ number of substitutions/site 


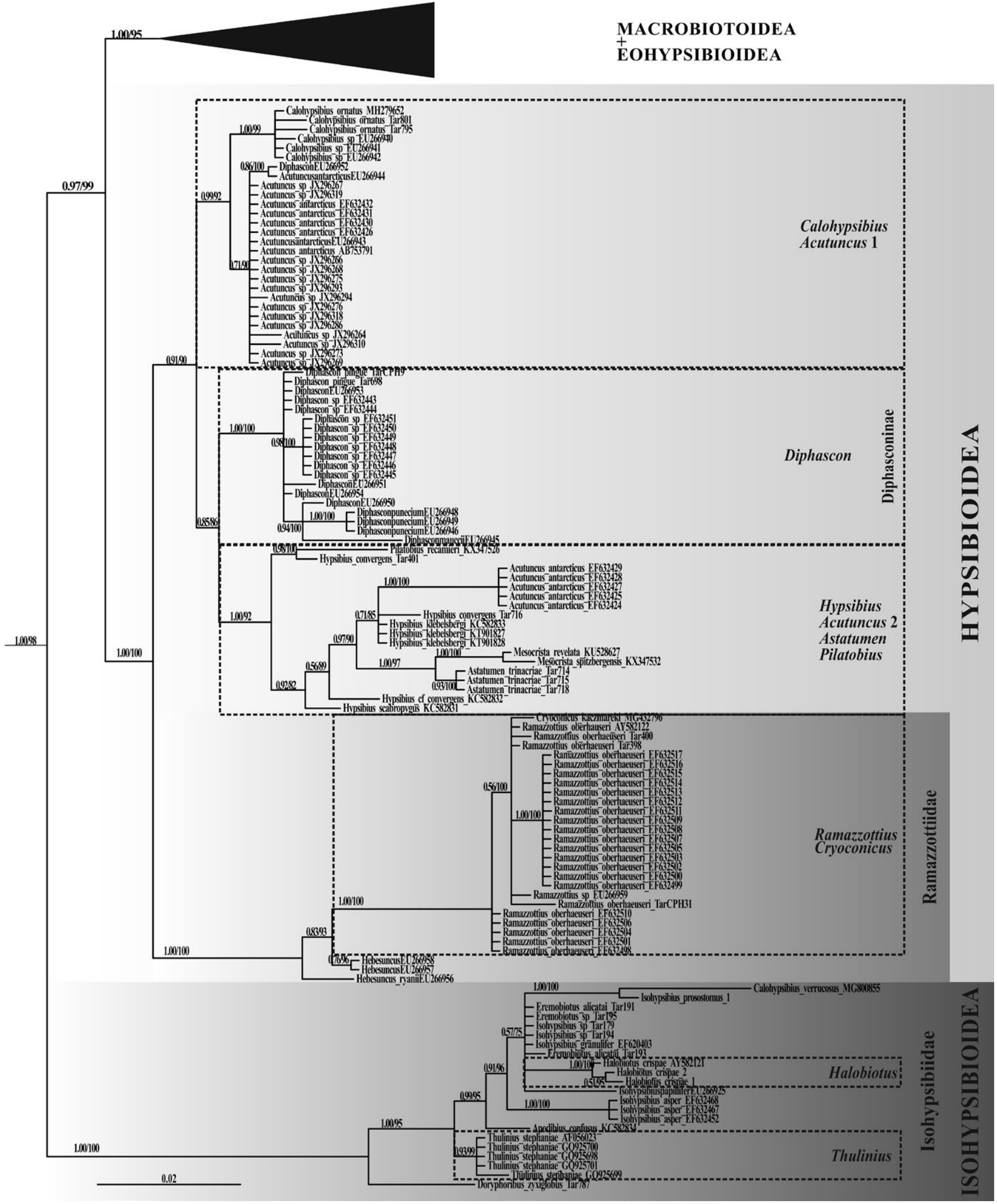

FI G U RE 2 Bayesian phylogram obtained with the nuclear 18S a2.0-9R for the superfamilies Hypsibioidea and Isohypsibioidea (Supporting information Table S1). First number above branches is posterior probabilities obtained in the BI. Second number is bootstrap support values from ML. Taxa are named following Supporting information Table S1. Orders, families, subfamilies genus and group of genera are indicated when monophyletic. Squares in different grey scales and dot limited squares highlight supported clades at different node levels. Scale bar $=$ number of substitutions/site 


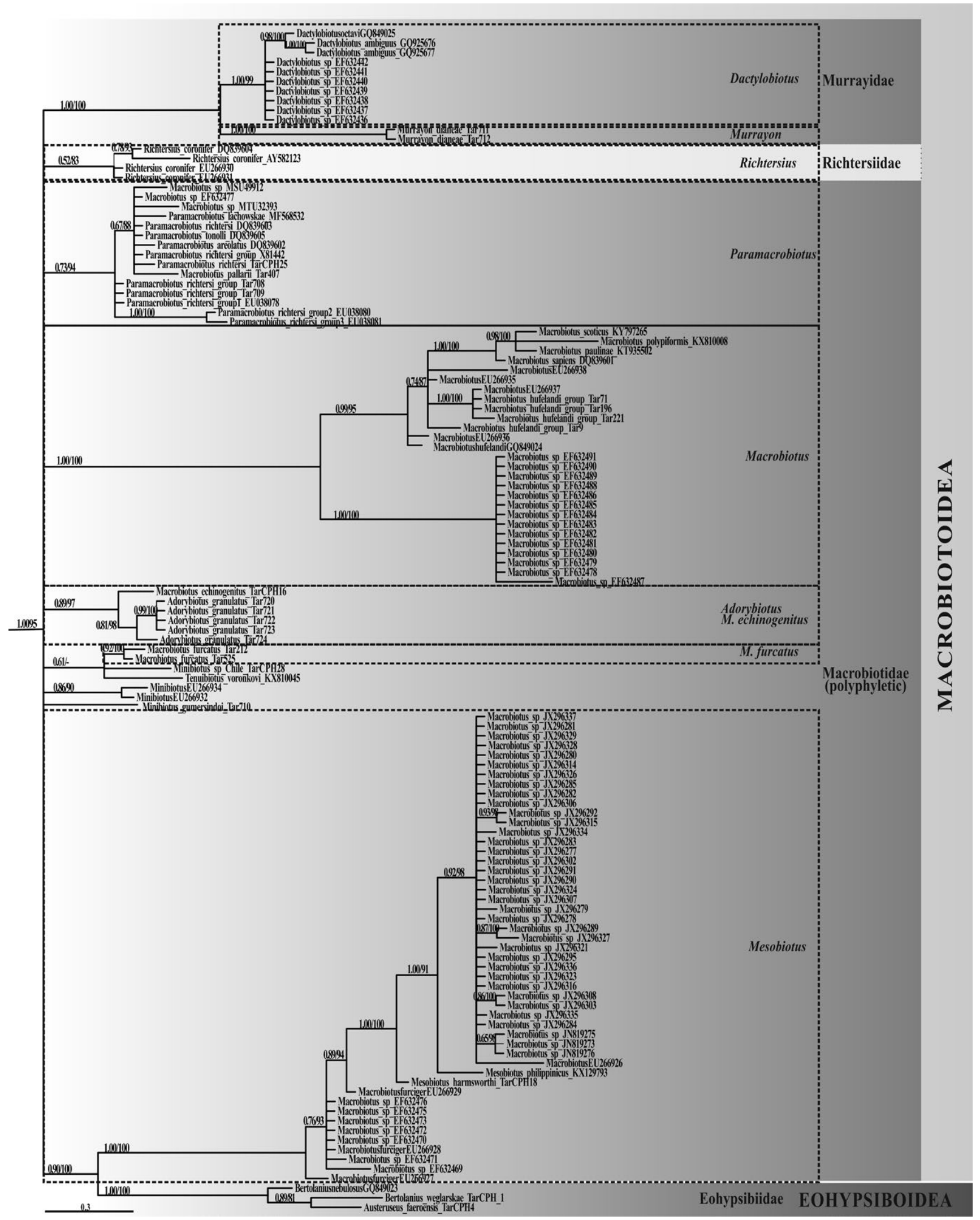

F I G U RE 3 Bayesian phylogram obtained with the nuclear 18S a2.0-9R for the superfamilies Macrobiotoidea and Eohypsibioidea (Supporting information Table S1). First number above branches is posterior probabilities obtained in the BI. Second number is bootstrap support values from ML. Taxa are named following Supporting information Table S1. Orders, families, genus and group of genera are indicated when monophyletic. Squares in different grey scales and dot limited squares highlight supported clades at different node levels. Scale bar $=$ number of substitutions/site 


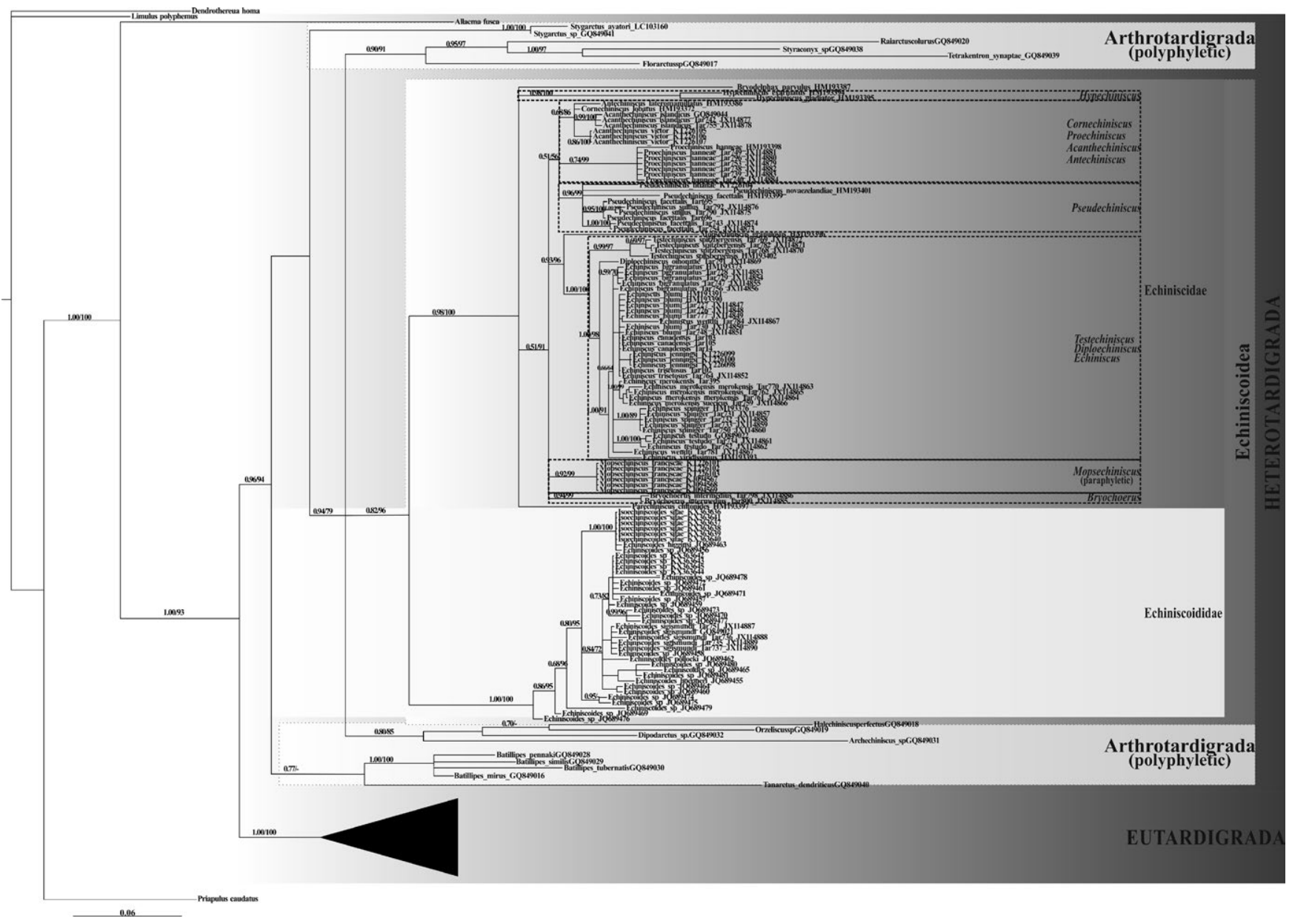

F I G U RE 4 Bayesian phylogram obtained with the nuclear 28S a-5b for the class Heterotardigrada (Supporting information Table S1). First number above branches is posterior probabilities obtained in the BI. Second number is bootstrap support values from ML. Taxa are named following Supporting information Table S1. Classes, orders, families, genus and group of genera are indicated. Squares in different grey scales and dot limited squares highlight supported clades at different node levels. Scale bar = number of substitutions/site

Macrobiotoidea, three phylogenetic lineages can be detected corresponding to families with the combined analysis (Figure 6): (a) Murrayidae, (b) Adorybiotus (maybe representing the family Richtersiidae, also supported with 28S; Figure 5) and (c) Macrobiotidae. Information with $18 \mathrm{~S}$ rRNA only showed support to family Murrayidae but not to Richtersiidae (Richtersius and Adoryiotus) and Macrobiotidae (due to the inclusion of Eohypsibiidae; Figure 3). The family Macrobiotidae can be subdivided into four phyletic lines (Figure 6): (a) Macrobiotus hufelandi group and Mesobiotus, (b) Macrobiotus furcatus, (c) Minibiotus gumersindoi and (d) Paramacrobiotus with Macrobiotus pallarii. Analysis with $18 \mathrm{~S}$ data included more biodiversity of species and genera, and five similar phyletic lines were supported (Figure 3): (a) Macrobiotus hufelandi group, (b) Mesobiotus, (c) Macrobiotus furcatus, (d) Paramacrobiotus with Macrobiotus pallarii and (e) Adorybitus with Macrobiotus echinogenitus.

The superfamily Hypsibioidea was divided into five clades with combined analysis (Figure 6): (a) Ramazzottiidae, (b) Diphasconinae, (c) Calohypsibiidae, (d) subfamily
Itaquasconinae with Hypsibius and (e) Acutuncus. When considering 18S data, similarly four phyletic lines were supported (Figure 2): (a) Ramazzottiidae, (b) Diphasconinae, (c) Calohypsibiidae with Acutuncus and (d) subfamily Itaquasconinae with Hypsibius and other Acutuncus specimens.

The superfamily Isohypsibioidea and the family Isohypsibiidae were divided into five phyletic lines (Figure 6): (a) Doryphoribius zyxiglobus, (b) Isohypsibius prosostomus, (c) Halobiotus with Isohypsibius sp., (d) Apodibius and (e) Eremobiotus. Within Isohypsibioidea, $18 \mathrm{~S}$ information exhibited low resolution (Figure 2). Contrary, $28 \mathrm{~S}$ data showed seven phyletic lines similar to those obtained in combined analysis (Figure 5): (a) Doryphoribius zyxiglobus; (b) Doryphoribius flavus; (c) Doryphoribius macrodon; (d) Isohypsibius granulifer; (e) Eremobiotus and Isohypsibius prosostomus; (f) Halobiotus, Isohypsibius species (including I. granulifer), Eremobiotus, Apodibius, Pseudobiotus kathmanae and Doryphoribius macrodon; and (g) Thulinius, Isohypsibius species (including I. dastychi), Pseudobitus megalonyx, Haplomacrobiotus and Hexapodibius. 


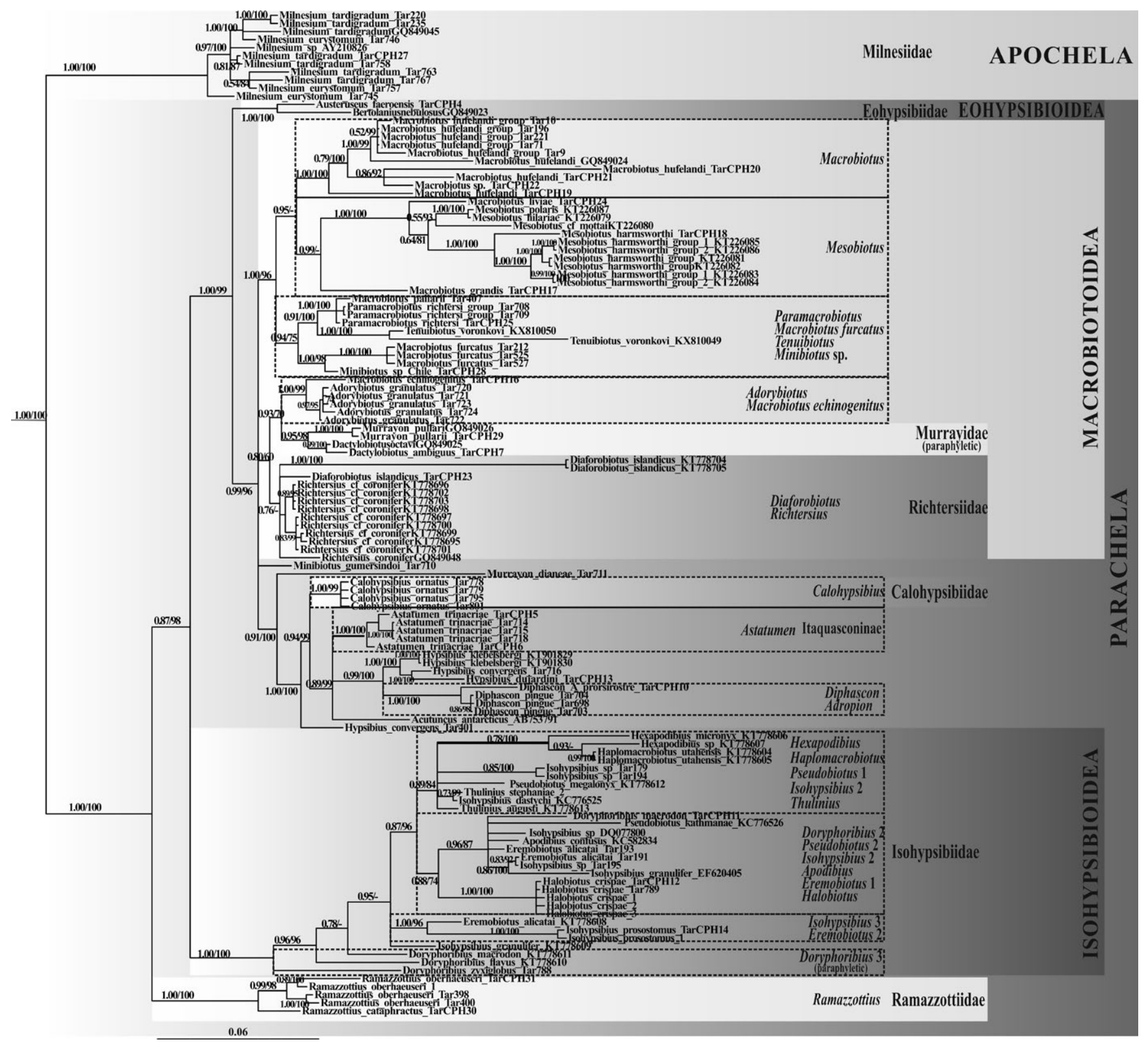

F I G U R E 5 Bayesian phylogram obtained with the nuclear 28S a-5b for the class Eutardigrada (Supporting information Table S1). First number above branches is posterior probabilities obtained in the BI. Second number is bootstrap support values from ML. Taxa are named following Supporting information Table S1. Orders, superfamilies, families, genus and group of genera are indicated. Squares in different grey scales and dot limited squares highlight supported clades at different node levels. Scale bar = number of substitutions/site

Monophyletic status of several genera was questioned (Figures 1-6): Mopsechiniscus, Isohypsibius, Doryphoribius, Richtersius, Macrobiotus, Minibiotus, Hypsibius, Hebesuncus, Acutuncus.

\section{4 | DISCUSSION}

\section{1 | Towards a natural classification of Tardigrada}

The main purpose of Tardigrada phylogenies has been supporting, modifying or rejecting current tardigrade classification on the phylogenetic basis. We present a more comprehensive Tardigrada phylogeny, which reliability relies on the inclusion of 63 tardigrade genera out of the 119 described (Tables 3 and Supporting information Table S1).

The three classes within Tardigrada (i.e., Heterotardigrada, Mesotardigrada and Eutardigrada) were created at the beginning of the XX century, being Mesotardigrada questioned in several occasions (Grothman et al., 2017; Ramazzotti \& Maucci, 1983). Eutardigrada monophyly has also been examined resulting dependent on the selection of outgroups for analyses (Guil \& Giribet, 2012). In that study, the order Apochela was independent of class Eutardigrada. 


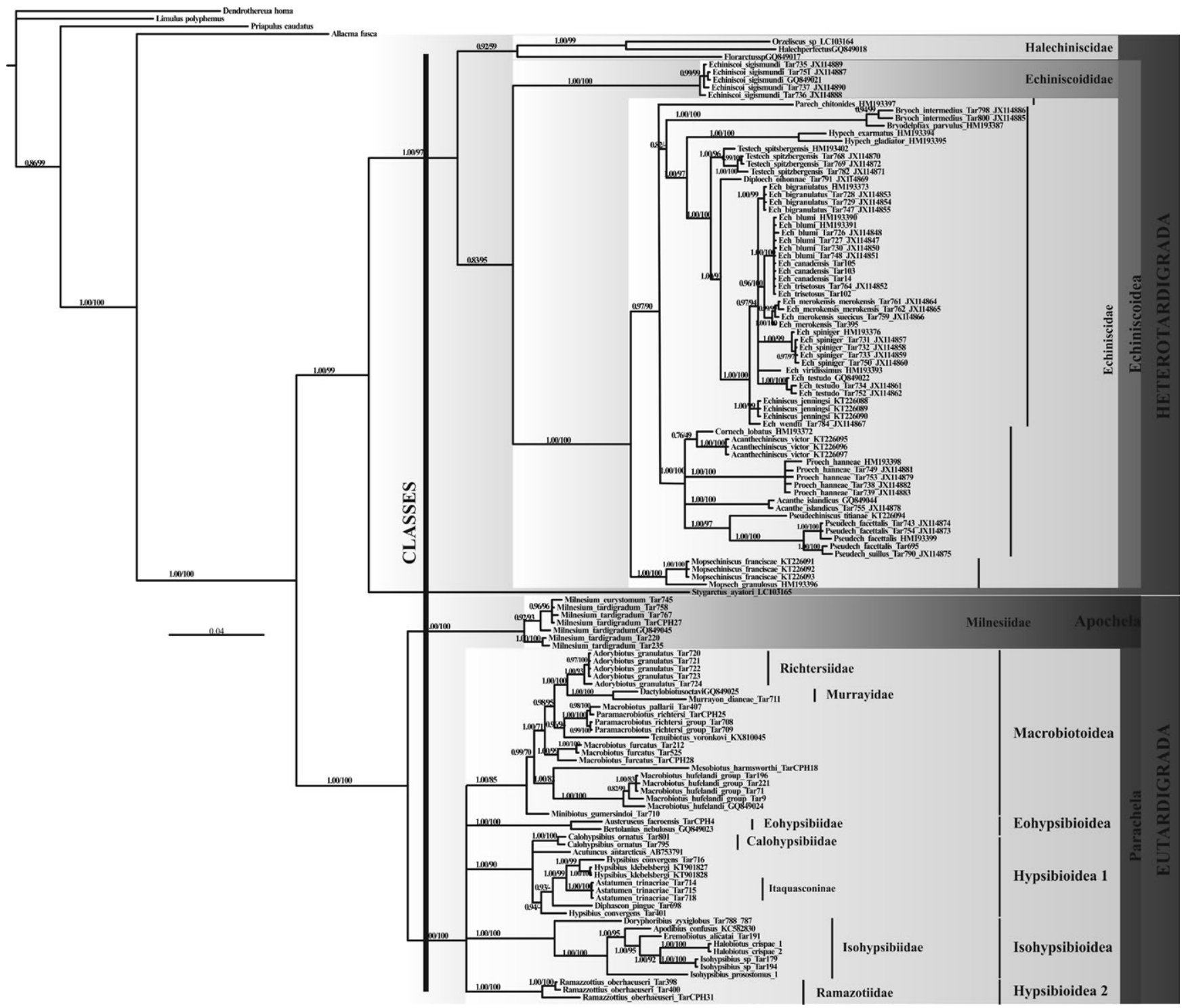

F I G U RE 6 Bayesian phylogram obtained combining nuclear genes 18S rRNA and 28S rRNA data set (Supporting information Table S1). First number above branches is posterior probabilities obtained in the BI. Second number is bootstrap support values from ML. Taxa are named following Supporting information Table S1. Classes, orders, families, superfamilies, genus and group of genera are indicated. Squares in different grey scales and dot limited squares highlight supported clades at different node levels. New node level for classes proposed is indicated with a vertical line. Scale bar = number of substitutions/site

Morphological differences among Tardigrada classes included: presence of appendages over the body, and morphology of claws and buccopharyngeal apparatuses (Bertolani, et al., 2014; Kristensen, 1987; Ramazzotti \& Maucci, 1983). Heterotardigrada includes heterotardigrade (marine and terrestrial) claws and buccopharyngeal apparatus (Figure 7a,b) with a great variety of appendages in head and body, while Mesotardigrada shows heterotardigrade (Echiniscoidea) claws (Figure 7a), eutardigrade buccopharyngeal apparatus and cirrus A on head (Kristensen, 1987; Pilato \& Binda, 2010; Ramazzotti \& Maucci, 1983). Contrary, within the class Eutardigrada can be found claws and buccopharyngeal apparatuses of apochelan and parachelan types (Figure $7 \mathrm{c}-\mathrm{f}$ ), while head appendages are present only in apochelans (peribuccal and cephalic papillae; Figure 8 and Schuster, Nelson, Grigarick, \& Christenberry, 1980) (parachelans showed in some cases sense organs but not appendages). So, differences between orders Apochela and Parachela include head appendages and claw morphology used to differentiate classes within Tardigrada. In addition, phylogenetic evidences show strong support to class Heterotardigrada, and current orders Apochela and Parachela (Figure 6). If considering class level as indicated in Figure 6, a new configuration with three classes (and doubtful Mesotardigrada) is evidenced as in other studies (Bertolani et al., 2014; Guidetti et al., 2009; Guil \& Giribet, 2012). So, two groups of evidences support the creation of a new class for the current order Apochela: (a) a unique morphology for claws and buccopharyngeal 

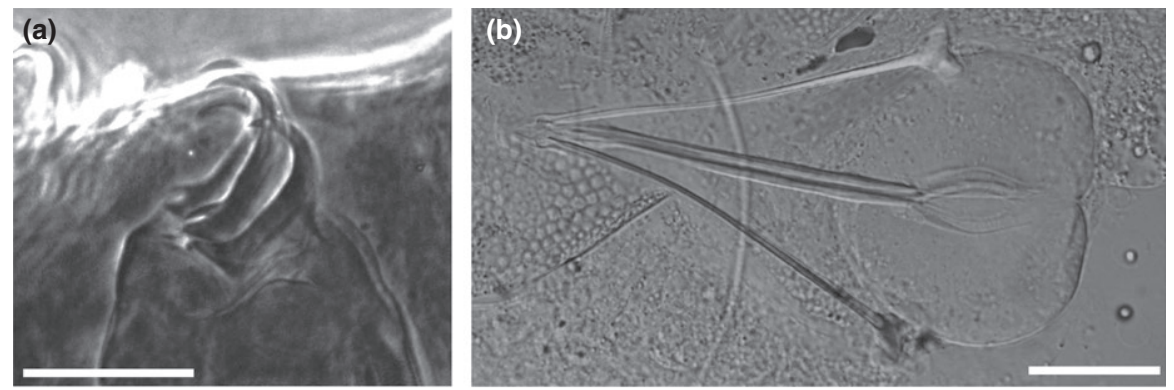

F I G URE 7 Images from optical microscope with phase contract of: $(a, b)$ claws and buccopharyngeal apparatus, respectively, of Echiniscus blumi representing the class Heterotardigrada; (c, d) claws and buccopharyngeal apparatus of Richtersius coronifer and Macrobiotus terminalis, respectively, representing the order Parachela of the class Eutardigrada; and $(e, f)$ claws and buccopharyngeal apparatus, respectively, of Milnesium tardigradum, representing the order Apochela of the class Eutardigrada. Scale bar $=20 \mu \mathrm{m}$
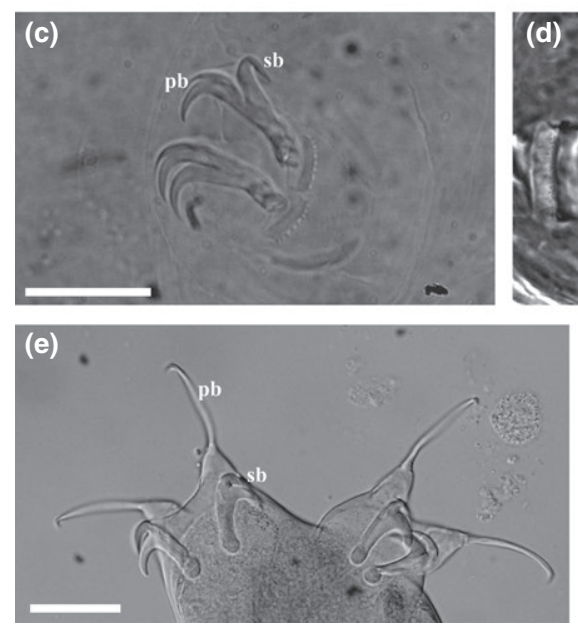

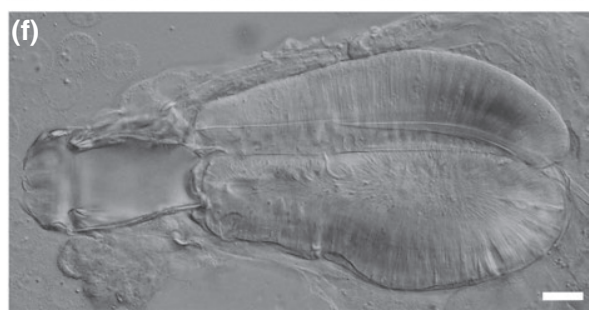

apparatus (Figure 7e,f) together with the presence of cephalic appendages (peribuccal and cephalic papillae; Figure 8 ) and (b) molecular support from Bayesian and likelihood analyses with 18S rRNA and 28S rRNA information (Figure 6). Consequently, we propose a new tardigrade class named Apotardigrada, following the former order name (Apochela) that indicates separate primary and secondary branches on claws. Within this new class Apotardigrada, the order Apochela is included, containing the family Milnesiidae, and genera and species composing this family as specified in Degma et al. (2018). Consequently, the class Eutardigrada diagnosis is amended excluding the cephalic appendages and claws with main and secondary branches separated. Since only parachelans remain within Eutardigrada, we propose to erect current superfamilies (Eohypsibioidea, Macrobiotoidea, Hypsibioidea, Isohypsibioidea) as orders within the class and suppression of order Parachela. Detailed taxonomic information is available in the Systematics section. Composition and diagnosis for former superfamilies (now orders) and families are as in Bertolani et al. (2014), Cesari et al. (2016), Guidetti et al. (2016) and Vecchi et al. (2016).

Internal relationships in Parachela confirmed clades as in other studies (e.g., Murrayidae, Macrobiotidae, Richtersiidae, Eohypsibiidae, Isohypsibiidae, Ramazzottiidae and Calohypsibiidae; Sands et al., 2008; Guil \& Giribet, 2012; Bertolani et al., 2014; Guidetti et al., 2016; Vecchi et al., 2016), but also remain open questions that need of further data and analyses to be solved. As an example, Eohypsibiidae confirmed its monophyly, but not Eohypsibioidea (Figure 6),

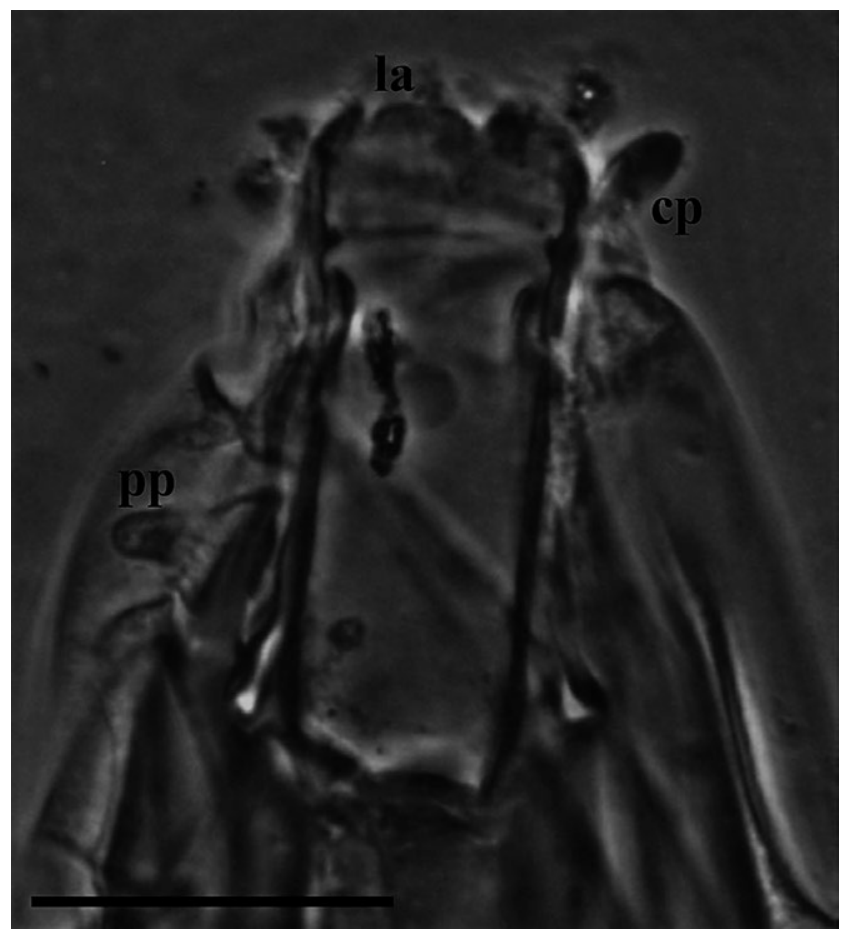

F IG URE 8 Image from optical microscope with phase contract of Milnesium tardigradum head showing: la, lamellae; $\mathbf{c p}$, cephalic papillae; and pp, peribuccal lamellae. Scale bar $=20 \mu \mathrm{m}$

being probably caused by differential biodiversity analysed (Bertolanius and Eohypsibius in Bertolani et al., 2014; and Austeruseus with Bertolanius in the present study; Figures 
3, 5 and 6). A second example refers to Adorybiotus, which was tentatively located within Richtersiidae by Guidetti et al (2016), but its inclusion within Richtersiidae is questioned by their and our results (Figures 3 and 6). Another issue is a possible polyphyletic status of Hypsibioidea (found when analysing individual genes, but not when they are combined) (as previously hypothesized: Kiehl, Dastych, D'Haese, \& Greven, 2007; Marley et al., 2011), even when five phylogenetic lineages can be distinguished within Hypsibioidea (Ramazzottiidae, Diphasconinae, Calohypsibiidae, Itaquasconinae with Hypsibius, and Acutuncus; Figure 6). And finally, two lines can be detected within Isohypsibioidea: the family Isohypsibiidae and Doryphoribius zyxiglobus (maybe a new family). The status of families and subfamilies of the five/seven phyletic lines within Isohypsibiidae (Doryphoribius zyxiglobus, Isohypsibius prosostomus, Halobiotus, Thulinius with Isohypsibius sp. and Apodibius with Eremobiotus, Pseudobiotus, Doryphoribius macrodon, Isohypsibius sp. and Isohypsibius granulifer; Figures 5 and 6) has to be evaluated.

Heterotardigrada internal classification has been problematic since the first molecular phylogenies, as they did not support the classical classification based on morphological similarities (Bertolani et al., 2014; Fujimoto, Jørgensen, \& Hansen, 2017; Guil \& Giribet, 2012; Guil, Machordom, et al., 2013; Jørgensen et al., 2011). Few attempts to organize the heterotardigrade classification have been done (Møbjerg, Kristensen, \& Jørgensen, 2016) despite to recent phylogenies that contradicted arthrotardigrade and echiniscoidean classifications (Fujimoto et al., 2017; Guil, Machordom, et al., 2013; Jørgensen, Faurby, Hansen, Møbjerg, \& Kristensen, 2010). Our results supported five phylogenetic lineages ((a) Hypechiniscus, Testechiniscus, Diploechiniscus and Echiniscus; (b) Bryodelphax and Bryochoerus; (c) Acanthechiniscus, Cornechiniscus and Proechiniscus; (d) Pseudechiniscus with Mopsechiniscus; and (e) Parechiniscus; Figure 6), also found by other authors with morphological and/or molecular information (Guil \& Giribet, 2012; Guil, Machordom, et al., 2013; Jørgensen, 1999; Jørgensen et al., 2011; Kristensen, 1987; Vecchi et al., 2016). Characters differentiating heterotardigrade families included place where claws were inserted (discs, toes, papillae, etc.), presence of certain cephalic appendages and presence of cuticular plates over dorsal and ventral surface (Kristensen, 1987; Møbjerg et al., 2016; Ramazzotti \& Maucci, 1983).

Here, we propose a new internal classification for the family Echiniscidae, with subfamilies and tribes (named after type genera) based on plates' presence and composition and shape of buccal sensory organs. We propose to create three subfamilies (Echiniscinae subfam. n., Pseudechiniscinae subfam. n. and Parechiniscinae subfam. n.) supported by molecular (Figure 6) and morphological information based on the presence of pseudosegmental and neck plates (see Systematic section for details). Subfamily Echiniscinae subfam. $n$. is divided into two tribes on the basis of the shape of cirri A, external and internal buccal cirri and phylogenetic information with molecular data (Figure 6): Echiniscini tribe $n$. and Bryodelphaxini tribe n. Three tribes organize internally the subfamily Pseudechiniscinae subfam. $n$. based on specific presence of pseudosegmental plates and phylogenetic support with molecular information (Figure 6): Cornechiniscini tribe n., Pseudechiniscini tribe $\mathrm{n}$. and Anthechiniscini tribe n. And two tribes are described within the subfamily Parechiniscinae subfam. n. on the basis of the presence of third median and/or head plate and phylogenetic support with molecular data (Figure 6): Parechiniscini tribe $n$. and Novechiniscini tribe n. Detailed taxonomic information, composition and diagnosis are available in the Systematics section.

\section{2 | Tardigrada representation in broader studies}

The use of tardigrades in animal phylogenies is broad but biased towards eutardigrades (especially from Milnesium, Macrobiotus and Hypsibius, see, e.g., Giribet et al., 1996; Dunn et al., 2008; Dunn et al., 2014; Laumer et al., 2015) with scarce use of heterotardigrades (from Pseudechiniscus, Echiniscus, Testechiniscus and Batillipes; Peterson \& Eernisse, 2001; Ryu et al.., 2007; Yamasaki, Fujimoto, \& Miyazaki, 2015). Artefacts obtained with biased diversity (as well as misidentifications) included in phylogenetic analyses, despite molecular data (from fragments to phylogenomics), and its relation with long-branch attraction (LBA) have been previously established (Pick et al., 2010). We propose, based on genetic diversity and our phylogenetic results, at least four biodiversity groups to be included on Metazoan and Ecdysozoa phylogenies: (a) heterotardigrades from the marine order Arthrotardigrada; (b) heterotardigrades from another more easy-to-find genera, such as the terrestrial Echiniscus (order Echiniscoidea); (c) one apotardigrade (newly created class Apotardigrada, formerly order Apochela, e.g., Milnesium); and (d) an eutardigrade (e.g., from the new created order Macrobiotoidea, formerly superfamily).

\section{3 | Evolution of the Clawless Apodibius}

Claw morphology is crucial in the tardigrade taxonomy and evolution, in contrast to buccopharyngeal apparatus, used in taxonomy and ecology but of homoplastic evolution (Guil \& Sanchez-Moreno, 2013; Guil, Jørgensen, Giribet, \& Kristensen, 2013). Evolution of claw reduction within Eutardigrada was proposed from morphology to evolve into two different lineages (former families Calohypsibiidae and Necopinatidae) being strongly criticized (Bertolani \& Biserov, 1996; Guil, Jørgensen, et al., 2013; Pilato \& Binda, 2010; Pilato, 1969a, 1969b, 1989). 
Originally, Calohypsibiidae included five genera and was created on the basis of the calohypsibius type of claw with two phyletic lines: one with normally developed claw (Calohypsibius) and the other with different grades of claw reduction (Parhexapodibius, Hexapodibius, Haplomacrobiotus and Haplohexapodibius) (Bertolani \& Biserov, 1996; Pilato, 1989; Pilato \& Binda, 2010). Phylogenetically, it has been demonstrated that former Calohypsibiidae was polyphyletic, with Calohypsibius within Hypsibioidea (Figure 6), and the claw reduced genera within Isohypsibioidea (creating a new family Hexapodibiidae; Cesari et al., 2016). The other lineage, Necopinatidae, was composed by Necopinatum and Apodibius, two claw reduced and clawless genera, respectively (Dabert et al., 2014; Degma et al., 2018; Pilato \& Binda, 2010). The assertion of the homoplastic evolution of claw reduction within Eutardigrada was confirmed when supported by redundant information of claw reduction in the eutardigrade morphological phylogeny (Guil, Machordom, et al., 2013).

In this sense, Apodibius inclusion, a clawless genus, within Isohypsibioidea (Figure 6; Dabert et al., 2014) allows hypothesizing its claw evolution from an original isohypsibius claws from an isohypsibioidean ancestor until claw lost in current Apodibius. Claws' modification in the soil-dwelling Apodibius could be related to its association with soil and related environments, with tiny spaces between soil grains, where a worm-like shape would favour their movement. Hohberg and Lang (2016) related Apodibius to Doryphoribius and Hexapodibius based on ventral lamina presence. However, Apodibius shares phylogenetic lineage with genera without ventral lamina, that is, Pseudobiotus, Eremobiotus, Isohypsibius and Thulinius within Isohypsibioidea (Figures 2 and 6). Then, ventral lamina presence (Doryphoribius, Hexapodibus, Haplomacrobiotus, Apodibius) or absence (Eremobiotus, Halobiotus, Isohypsibius, Pseudobiotus, Thulinius) is homoplastic within the Isohypsibiodea clade (Figure 6), confirming a homoplastic evolution of the buccopharyngeal apparatus and its structures (Guil, Machordom, et al., 2013). Maybe, diversification to different feeding habits within distinct phylogenetic lineages, and so homoplastic evolution of the buccopharyngeal apparatus, can be related to guarantee of food roles execution within ecosystems (Guil \& Sanchez-Moreno, 2013; Guil, Jørgensen, et al., 2013). These hypotheses, relating claw and buccopharyngeal apparatus evolution with ecology, open a new research line within tardigrades that need of further genetic, developmental, taxonomical and ecological information to be clarified.

\section{5 | SYSTEMATICS}

Tardigrada Doyère, 1840

Class Mesotardigrada Rahm, 1937 nomen dubium (diagnosis as in Ramazzotti \& Maucci, 1983 and Grothman et al., 2017)
Diagnosis: Cirri A present. With heterotardigrada-like spines. Heterotardigrade-like claws with no differentiation in main and secondary branches. Pharyngeal bulb with Eutardigrada-like macroplacoids.

Class Apotardigrada (Schuster et al., 1980) comb. n.

Diagnosis: Papillae around the mouth (peribuccal papillae) and two lateral papillae on the head (cephalic papillae) are present. Claws with completely separated primary and secondary branches. Elongated pharyngeal bulb without placoids.

Composition:

Order Apochela Schuster et al., 1980 (same description as the class)

Family Milnesiidae Ramazzotti, 1962

Type genus: Milnesium Doyère, 1840

Other genera: Bergtrollus, Limmenius, Milnesioides

\section{Class Eutardigrada Marcus, 1927}

Diagnosis (amended): Cephalic appendages are absent. Claws with primary and secondary branches fused, very rarely claws are reduced or lost. Pharyngeal bulb has placoids that very rarely are reduced or lost.

Composition: superfamilies elevated to orders; descriptions and composition of orders as in Bertolani et al., 2014; Cesari et al., 2016; Guidetti et al, 2016; Vecchi et al., 2016:

Order Eohypsibioidea Bertolani \& Kristensen, 1987 comb. n.

Order Hypsibioidea Pilato, 1969 comb. n.

Order Macrobiotoidea Thulin, 1928 comb. n.

Order Isohypsibioidea Sands et al., 2008 comb. n.

Class Heterotardigrada Marcus, 1927 (description as in Kristensen, 1987)

Diagnosis: Tardigrada with cephalic, trunk and leg appendages. Gonopore separated from anus. Malpighian tubules lacking. Placoids consisting of three $\mathrm{CaCO}_{3}$ elements or three delicate, bar-shaped cuticular structures. Composition: Taxonomic accounts and classification as in Kristensen, 1987, Degma et al., 2018, and Fontoura, Bartels, Jørgensen, Kristensen, \& Hansen, 2017.

Order Arthrotardigrada Marcus, 1927 (classification as in Degma et al., 2018)

Order Echiniscoidea Richters, 1926 (description as in Kristensen, 1987)

Diagnosis: Heterotardigrada without toes on the legs. Median cirrus absent.

Family Echiniscidae Thulin, 1928 (description as in Kristensen, 1987).

Diagnosis: Echiniscoidea without seminal receptacles. Dorsal plates present. Adults with four claws on each leg. Semi-aquatic and terrestrial. Cryptobiosis exhibited by most genera.

Composition:

Subfamily Echiniscinae subfam. n. 
Diagnosis: Echinisicidae without pseudosegmental plates.

Tribe Echiniscini tribe n.

Diagnosis: Cirri A are filaments with cirriphores. External and internal buccal cirri with cirriphores. Composition: Echiniscus C.A.S. Schultze, 1840 (type genus), Diploechiniscus Vicente et al., 2013, Testechiniscus Kristensen, 1987, Hypechiniscus Thulin, 1928.

Tribe Bryodelphaxini tribe $\mathrm{n}$.

Diagnosis: Cirri A are filaments with cirriphores. External and internal buccal cirri without cirriphores.

Composition: Bryodelphax Thulin, 1928 (type genus), Bryochoerus Marcus, 1936.

Subfamily Pseudechiniscinae subfam. $\mathrm{n}$.

Diagnosis: Echinisicidae with pseudosegmental plates.

Tribe Cornechiniscini tribe $\mathrm{n}$.

Diagnosis: Unpaired pseudosegmental plates I' and III'.

Composition: Cornechiniscus Maucci \& Ramazzotti, 1981 (type genus), Acanthechiniscus Vecchi et al., 2016, Proechiniscus Kristensen, 1987.

Tribe Pseudechiniscini tribe $\mathrm{n}$.

Diagnosis: Only pseudosegmental plate IV' present.

Composition: Pseudechiniscus Thulin, 1911 (type genus), Mopsechiniscus du Bois-Reymond Marcus, 1944 (tentatively located in this tribe, waiting for more molecular analyses that will clarify its monophyletic status)

Tribe Anthechiniscini tribe $\mathrm{n}$.

Diagnosis: Present (Paired or unpaired) pseudosegmental plates II', III' and IV'.

Composition: Antechisniscus Kristensen, 1987 (type genus), Multipseudechiniscus Schulte \& Miller, 2011.

Subfamily Parechiniscinae subfam. $n$.

Diagnosis: Neck dorsal plate absent.

Tribe Novechiniscini tribe $\mathrm{n}$.

Diagnosis: Median plate m3 absent.

Composition: Novechiniscus Kristensen, 1987

(type genus).

Tribe Parechiniscini tribe $\mathrm{n}$.

Diagnosis: Head plate absent.

Composition: Parechiniscus Cuénot, 1926 (type genus).

\section{ACKNOWLEDGEMENTS}

This work was supported by several Spanish and European administrations including a postdoctoral contract awarded to N.G., under the JAE-DOC programme of the Consejo
Superior de Investigaciones Científicas (CSIC) in the Museo Nacional de Ciencias Naturales of Madrid (MNCN-CSIC), and two projects under the European Marie Curie programme (grants numbers: PERG07-GA-2010-268289 and FP7-PEOPLE-2010-RG).

\section{ORCID}

Noemi Guil (D) http://orcid.org/0000-0002-0116-4926

\section{REFERENCES}

Aguinaldo, A. M., Turbeville, J. M., Linford, L. S., Rivera, M. C., Raff, R., \& Lake, J. A. (1997). Evidence for a clade of nematodes, arthropods and other moulting animals. Nature, 387, 489-493. https://doi. org/10.1038/387489a0

Bertolani, R., \& Biserov, V. I. (1996). Leg and claw adaptations in soil tardigrades, with erection of two new genera of Eutardigrada, Macrobiotidae: Pseudohexapodibius and Xerobiotus. Invertebrate Biology, 115, 299-304. https://doi.org/10.2307/3227019

Bertolani, R., Guidetti, R., Marchioro, T., Altiero, T., Rebecchi, L., \& Cesari, M. (2014). Phylogeny of Eutardigrada: New molecular data and their morphological support lead to the identification of new evolutionary lineages. Molecular Phylogenetics and Evolution, 76, 110-126. https://doi.org/10.1016/j.ympev.2014.03.006.

Boeckmann, B., Marcet-Houben, M., Rees, J. A., Forslund, K., HuertaCepas, J., Muffato, M., ... Gabaldón, T. (2015). Quest for orthologs entails quest for tree of life: In search of the gene stream. Genome Biology and Evolution, 7, 1988-1999. https://doi.org/10.1093/gbe/ evv121

Burki, F. (2014). The eukaryotic tree of life from a global phylogenomic perspective. Cold Spring Harbor Perspectives in Biology, 6, a016147. https://doi.org/10.1101/cshperspect.a016147

Cesari, M., Vecchi, M., Palmer, A., Bertolani, R., Pilato, G., Rebecchi, L., \& Guidetti, R. (2016). What if the claws are reduced? Morphological and molecular phylogenetic relationships of the genus Haplomacrobiotus May, 1948 (Eutardigrada, Parachela). Zoological Journal of the Linnean Society, 178, 819-827. https:// doi.org/10.1111/zoj.12424.

Dabert, M., Dastych, H., Hohberg, K., \& Dabert, J. (2014). Phylogenetic position of the enigmatic clawless eutardigrade genus Apodibius Dastych, 1983 (Tardigrada), based on 18S and 28S rRNA sequence data from its type species A. confusus. Molecular Phylogenetics and Evolution, 70, 70-75. https://doi.org/10.1016/j. ympev.2013.09.012.

Darriba, D., Taboada, G. L., Doallo, R., \& Posada, D. (2012). jModelTest 2: More models, new heuristics and parallel computing. Nature Methods, 9, 772. https://doi.org/10.1038/nmeth.2109.

Degma, P., Bertolani, R., \& Guidetti, R. (2018). Actual checklist of Tardigrada species (2009-2018, 34th Edition: 30-06-2018) [Internet]. [17-August-2018]. Retrieved from: https://www.evozoo. unimore.it/site/home/documento1080026927.html

Dunn, C. W., Giribet, G., Edgecombe, G., \& Hejnol, A. (2014). Animal phylogeny and its evolutionary implications. Annual Review of Ecology, Evolution, and Systematics, 45, 371-395. https://doi. org/10.1146/annurev-ecolsys-120213-091627.

Dunn, C. W., Hejnol, A., Matus, D. Q., Pang, K., Browne, W. E., Seaver, E., ... Giribet, G. (2008). Broad phylogenomic sampling improves 
resolution of the Animal Tree of Life. Nature, 452, 745-750. https:// doi.org/10.1038/nature06614.

Erdmann, W., \& Kaczmarek, Ł. (2017). Tardigrades in space research - past and future. Origins of Life and Evolution of Biospheres, 47, 545-553. https://doi.org/10.1007/s11084-016-9522-1.

Fontoura, P., Bartels, P. J., Jørgensen, A., Kristensen, R. M., \& Hansen, A. J. (2017). A dichotomous key to the genera of the Marine Heterotardigrades (Tardigrada). Zootaxa, 4294, 1-45. https://doi. org/10.11646/zootaxa.4294.1.1.

Fontoura, P., \& Pilato, G. (2007). Diphascon (Diphascon) faialense sp. nov. a new species of Tardigrada (Eutardigrada, Hypsibiidae) from the Azores and a key to the species of the D. pingue group. Zootaxa, 1589, 47-55.

Fujimoto, S., Jørgensen, A., \& Hansen, J. G. (2017). A molecular approach to arthrotardigrade phylogeny (Heterotardigrada, Tardigrada). Zoologica Scripta, 46, 496-505. https://doi.org/10.1111/zsc.12221.

Garey, J. R., Nelson, D. R., Mackey, L. J., \& Li, J. (1999). Tardigrade phylogeny: Congruency of morphological and molecular evidence. Zoological Anzeiger, 238, 205-210.

Giribet, G. (2016a). Genomics and the animal tree of life: Conflicts and future prospects. Zoologica Scripta, 45, 14-21. https://doi. org/10.1111/zsc.12215.

Giribet, G. (2016b). New animal phylogeny: Future challenges for animal phylogeny in the age of phylogenomics. Organisms Diversity \& Evolution, 16, 419-426. https://doi.org/10.1007/ s13127-015-0236-4.

Giribet, G., Carranza, S., Baguña, J., Riutort, M., \& Ribera, C. (1996). First molecular evidence for the existence of a Tardigrada + Arthropoda clade. Molecular Biology and Evolution, 13, 76-84. https://doi.org/10.1093/oxfordjournals.molbev.a025573

Grothman, G. T., Johansson, C., Chilton, G., Kagoshima, H., Tsujimoto, M., \& Suzuki, A. C. (2017). Gilbert Rahm and the status of Mesotardigrada Rahm, 1937. Zoological Science, 34, 5-10. https:// doi.org/10.2108/zs160109.

Guidetti, R., Altiero, T., \& Rebecchi, L. (2011). On dormancy strategies in tardigrades. Journal of Insect Physiology, 57, 567-576. https:// doi.org/10.1016/j.jinsphys.2011.03.003.

Guidetti, R., \& Bertolani, R. (2005). Tardigrade taxonomy: An updated check list of the taxa and a list of characters used in their identification. Zootaxa, 845, 1-46. https://doi.org/10.11646/ zootaxa.845.1.1.

Guidetti, R., Rebecchi, L., Bertolani, R., Jönsson, K. I., Kristensen, R. M., \& Cesari, M. (2016). Morphological and molecular analyses on Richtersius (Eutardigrada) diversity reveal its new systematic position and lead to the establishment of a new genus and a new family within Macrobiotoidea. Zoological Journal of the Linnean Society, 178, 834-845. https://doi.org/10.1111/zoj.12428.

Guidetti, R., Schill, R., Bertolani, R., Dandekar, T., \& Wolf, M. (2009). New molecular data for tardigrade phylogeny, with the erection of Paramacrobiotus gen. nov. Zoological Systematics and Evolutionary Research, 47, 315-321. https://doi. org/10.1111/j.1439-0469.2009.00526.x.

Guil, N. (2011). Molecular approach to micrometazoans. Are they here, there and everywhere? In D. Fontaneto (Ed.), Biogeography of microorganisms, is everything small everywhere? (pp. 284-306). Cambridge, UK: Cambridge University Press.

Guil, N., \& Giribet, G. (2009). Fine scale population structure in the Echiniscus blumi-canadensis series (Heterotardigrada, Tardigrada) in an Iberian mountain range-When morphology fails to explain genetic structure. Molecular Phylogenetics and Evolution, 51, 606613. https://doi.org/10.1016/j.ympev.2009.02.019

Guil, N., \& Giribet, G. (2012). A comprehensive molecular phylogeny of tardigrades-adding genes and taxa to a poorly resolved phylumlevel phylogeny. Cladistics, 28, 21-49. https://doi.org/10.1016/j. ympev.2009.02.019.

Guil, N., Jørgensen, A., Giribet, G., \& Kristensen, R. M. (2013). Congruence between molecular phylogeny and cuticular design in Echiniscoidea (Tardigrada, Heterotardigrada). Zoological Journal of the Linnean Society, 169, 713-736. https://doi.org/10.1111/zoj.12090.

Guil, N., Machordom, A., \& Guidetti, R. (2013). High level of phenotypic homoplasy among eutardigrades (Tardigrada) based on morphological and total evidence phylogenetic analyses. Zoological Journal of the Linnean Society, 169, 1-26. https://doi.org/10.1111/ zoj. 12046 .

Guil, N., \& Sanchez-Moreno, S. (2013). Fine-scale patterns in micrometazoans: Tardigrade diversity, community composition and trophic dynamics in leaf litter. Systematics and Biodiversity, 11, 181-193. https://doi.org/10.1080/14772000.2013.798370.

Hall, T. A. (1999). BioEdit: A user-friendly biological sequence alignment editor and analysis program for Windows 95/98/NT. Nucleic Acids Symposium, 41, 95-98.

Hashimoto, T., Horikawa, D. D., Saito, Y., Kuwahara, H., Kozuka-Hata, H., Shin, T., ... Kunieda, T. (2016). Extremotolerant tardigrade genome and improved radiotolerance of human cultured cells by tardigrade-unique protein. Nature. Communications, 7, 12808. https:// doi.org/10.1038/ncomms12808.

Hejnol, A., Obst, M., Stamatakis, A., Ott, M., Rouse, G. W., Edgecombe, G. D., ... Jondelius, U. (2009). Assessing the root of bilaterian animals with scalable phylogenomic methods. Proceedings of the Royal Society B, 276, 4261-4270 https://doi.org/10.1098/rspb.2009.0896

Hohberg, K., \& Lang, B. (2016). The feeding apparatus and taxonomic position of clawless Apodibius confusus Dastych, 1983 (Tardigrada: Isohypsibiidae). Zoological Journal of the Linnean Society, 178, 828-833. https://doi.org/10.1111/zoj.12408

Horikawa, D. D., Kunieda, T., Abe, W., Watanabe, M., Nakahara, Y., Yukuhiro, F., ... Okuda, T. (2008). Establishment of a rearing system of the extremotolerant tardigrade Ramazzottius varieornatus: A new model animal for Astrobiology. Astrobiology, 8, 549-556. https://doi.org/10.1089/ast.2007.0139.

Huelsenbeck, J. P., \& Ronquist, F. (2001). MRBAYES: Bayesian inference of phylogenetic trees. Bioinformatics Applications Note, 17, 754-755. https://doi.org/10.1093/bioinformatics/17.8.754.

Jönsson, K. I., Rabbow, E., Schill, R. O., Harms-Ringdahl, M., \& Rettberg, P. (2008). Tardigrades survive exposure to space in low Earth orbit. Current Biology, 18, R729-R731. https://doi. org/10.1016/j.cub.2008.06.048.

Jørgensen, A. (1999). Cladistic analysis of the Echiniscidae Thulin, 1928 (Tardigrada: Heterotardigrada: Echiniscoidea). Steenstrupia, 25,38679 .

Jørgensen, A., Faurby, S., Hansen, J. G., Møbjerg, N., \& Kristensen, R. M. (2010). Molecular phylogeny of Arthrotardigrada (Tardigrada). Molecular Phylogenetics and Evolution, 54, 1006-1015. https://doi. org/10.1016/j.ympev.2009.10.006

Jørgensen, A., Møbjerg, N., \& Kristensen, R. M. (2011). Phylogeny and evolution of the Echiniscidae (Echiniscoidea, Tardigrada)-an investigation of the congruence between molecules and morphology. Zoological Systematics and Evolutionary Research, 49, 6-16. https://doi.org/10.1111/j.1439-0469.2010.00592.x 
Kaczmarek, L., Gawlak, M., Bartels, P. J., Nelson, D. R., \& Roszkowska, M. (2017). Revision of the gnus Paramacrobiotus Guidetti et al., 2009 with the description of a new species, re-descriptions and a Key. Annales Zoologici, 67, 627-656. https://doi.org/10.3161/0003 4541ANZ2017.67.4.001

Kaczmarek, L., Goldyn, B., Prokop, Z. M., \& Michalczyck, L. (2011). New records of Tardigrada from Bulgaria with the description of Macrobiotus binieki sp. nov. (Eutardigrada: Macrobiotidae) and a key to the species of the harmsworthi group. Zootaxa, 2781, 29-39.

Kaczmarek, L., \& Michalczyk, L. (2017). The Macrobiotus hufelandi group (Tardigrada) revisited. Zootaxa, 4363, 101-123. https://doi. org/10.11646/zootaxa.4363.1.4

Kiehl, E., Dastych, H., D'Haese, H., \& Greven, H. (2007). The 18S rDNA sequences support polyphyly of the Hypsibiidae (Eutardigrada). Journal of Limnology, 66, 21-25. https://doi.org/10.4081/jlimnol.2007.s1.21

Kristensen, R. M. (1987). Generic revision of the Echiniscidae (Hetrotardigrada), with a discussion of the origin of the family. Selected Symposia and Monograph UZI, 1, 261-335.

Laumer, C. E., Bekkouche, N., Kerbl, A., Goetz, F., Neves, R. C., Sørensen, M. V., ... Worsaae, K. (2015). Spiralian phylogeny informs the evolution of microscopic lineages. Current Biology, 25, 2000-2006. https://doi.org/10.1016/j.cub.2015.06.068

Marley, N. J., Kaczmarek, L., Gawlak, M., Bartels, P. J., Nelson, D. R., Roszkowska, M. D. S., \& Degma, P. (2018). A clarification for the subgenera of Paramacrobiotus Guidetti, Schill, Bertolani, Dandekar and Wolf, 2009, with respect to the International Code of Zoological Nomenclature. Zootaxa, 4407, 130-134. https://doi.org/10.11646/ zootaxa.4407.1.9.

Marley, N. J., McInnes, S. J., \& Chester, J. S. (2011). Phylum Tardigrada: A re-evaluation of the Parachela. Zootaxa, 2819, 51-64. https://doi. org/10.5281/zenodo.201757.

Michalczyck, L., Welnicz, W., Frohme, M., \& Kaczmarek, L. (2012). Redescriptions of three Milnesium Doyère, 1840 taxa (Tardigrada: Eutardigrada: Milnesiidae), including the nominal species for the genus. Zootaxa, 3154, 1-20.

Michalczyk, L., \& Kaczmarek, L. (2005). The first record of the genus Calohypsibius Thulin, 1928 (Eutardigrada: Calohypsibiidae) from Chile (South America) with a description of a new species Calohypsibius maliki. New Zealand Journal of Zoology, 32, 287-292.

Michalczyk, L., \& Kaczmarek, L. (2010). Description of Doryphoribius dawkinsi, a new species of Tardigrada (Eutardigrada: Hypsibiidae) from the Costa Rican highlands, with the key to the genus Doryphoribius. Zootaxa, 2393, 46-58.

Møbjerg, N., Halberg, K. A., Jørgensen, A., Persson, D., Bjørn, M., Ramløv, H., \& Kristensen, R. M. (2011). Survival in extreme environments - on the current knowledge of adaptations in tardigrades. Acta Physiology, 202, 409-420. https://doi. org/10.1111/j.1748-1716.2011.02252.x.

Møbjerg, N., Kristensen, R. M., \& Jørgensen, A. (2016). Data from new taxa infer Isoechiniscoides gen. nov. and increase the phylogenetic and evolutionary understanding of echiniscoidid tardigrades (Echiniscoidea: Tardigrada). Zoological Journal of the Linnean Society, 178, 804-818. https://doi.org/10.1111/zoj.12500.

Nelson, D. R., Guidetti, R., \& Rebecchi, L. (2015). Phylum Tardigrada. In D. C. Rogers, J. Thorp (Eds.), Ecology and general biology: Thorp and Covich's freshwater invertebrates (pp. 347-380). London, UK: Academic Press.
Nguyen, L. T., Schmidt, H. A., von Haeseler, A., \& Minh, B. Q. (2015). IQ-TREE: A fast and effective stochastic algorithm for estimating maximum likelihood phylogenies. Molecular Biology and Evolution, 32, 268-274. https://doi.org/10.1093/molbev/ msu300.

Nylander, J. A. A. (2004). MrModeltest v2. Program. Distributed by the author. Uppsala, Sweden: Evolutionary Biology Centre, Uppsala University.

Persson, D., Halberg, K. A., Jørgensen, A., Ricci, C., Møbjerg, N., \& Kristensen, R. M. (2011). Extreme stress tolerance in tardigrades: Surviving space conditions in low earth orbit. Journal of Zoological Systematics and Evolutionary Research, 49, 90-97. https://doi. org/10.1111/j.1439-0469.2010.00605.x.

Peterson, K. J., \& Eernisse, D. J. (2001). Animal phylogeny and the ancestry of bilaterians: Inferences from morphology and 18S rDNA gene sequences. Evolution \& Development, 3, 170-205. https://doi. org/10.1046/j.1525-142x.2001.003003170.x.

Pick, K. S., Philippe, H., Schreiber, F., Erpenbeck, D., Jackson, D. J., Wrede, P., ... Relationships, P. T. S. N. A. N. (2010). Improved phylogenomic taxon sampling noticeably affects nonbilaterian relationships. Molecular Biology and Evolution, 27, 1983-1987. https://doi. org/10.1093/molbev/msq089

Pilato, G. (1969a). Evoluzione e nuova sistemazione degli Eutardigrada. Bolletino Di Zoologia, 36, 327-345.

Pilato, G. (1969b). Schema per un nuova sistemazione delle famiglie e dei generi degli Eutardigrada. Serie IV: Bollettino Delle Sedute Dell'accademia Gioenia Di Scienze Naturali in Catania X, Serie IV, 181-193

Pilato, G. (1989). Phylogenesis and systematic arrangement of the family Calohypsibiidae Pilato, 1969 (Eutardigrada). Journal of Zoological Systematics and Evolutionary Research, 27, 8-13. https://doi.org/10.1111/j.1439-0469.1989.tb00433.x.

Pilato, G., \& Binda, M. G. (2010). Definition of families, subfamilies, genera and subgenera of the Eutardigrada, and keys to their identification. Zootaxa, 2404, 1-54. https://doi.org/10.5281/ zenodo.194138.

Ramazzotti, G., \& Maucci, W. (1983). Il phylum Tardigrada. III edizione riveduta e aggiornata. Memorie Dell'istituto Italiano Di Idrobiologia Dott Marco De Marchi, 41, 1-1012.

Rebecchi, L., Altiero, T., Guidetti, R., Cesari, M., Bertolani, R., Negroni, M., \& Rizzo, A. M. (2009). Tardigrade resistance space effect: first results of experiments on the LIFE-TARSE Mission on FOTON-M3 (September 2007). Astrobiology, 9, 581-591. https:// doi.org/10.1089/ast.2008.0305

Roeding, F., Hagner-Holler, S., Ruhberg, H., Ebersberger, I., von Haeseler, A., Kube, M., ... Burmester, T. (2007). EST sequencing of Onychophora and phylogenomic analysis of Metazoa. Molecular Phylogenetics and Evolution, 45, 942-951. https://doi.org/10.1016/j. ympev.2007.09.002

Rokas, A., Kruger, D., \& Carroll, S. B. (2005). Animal evolution and the molecular signature of radiations compressed in time. Science, 310, 1933-1938. https://doi.org/10.1126/science.1116759

Ronquist, F., \& Huelsenbeck, J. P. (2003). MrBayes 3: Bayesian phylogenetic inference under mixed models. Bioinformatics Applications Note, 19, 1572-1574. https://doi.org/10.1093/bioinformatics/btg180

Ryu, S. H., Lee, J. M., Jang, K. H., Choi, E. H., Park, S. J., Chan, C. Y., ... Hwang, U. W. (2007). Partial mitochondrial gene arrangements support a close relationship between Tardigrada and Arthropoda. Molecules \& Cells, 3, 351-357. 
Sands, C. J., McInnes, S. J., Marley, N., Goodall-Copestake, W. P., Convey, P., \& Linse, K. (2008). Phylum Tardigrada: An individual approach. Cladistics, 24, 1-11. https://doi. org/10.1111/j.1096-0031.2008.00219.x

Schuster, R. O., Nelson, D. R., Grigarick, A. A., \& Christenberry, D. (1980). Systematic criteria of the Eutardigrada. Transactions of the American Microscopical Society, 99, 284-303. https://doi. org/10.2307/3226004

Schwendinger, P. J., \& Giribet, G. (2005). The systematics of the southeast Asian genus Fangensis Rambla (Opiliones: Cyphophthalmi: Stylocellidae). Invertebrate Systematics, 19, 297-323. https://doi. org/10.1071/IS05023

Trygvadóttir, B. V., \& Kristensen, R. M. (2001). Eohypsibiidae (Eutardigrada, Tardigrada) from the Faroe Islands with the description of a new genus containing three new species. Zootaxa, 2886, 39-62. https://doi.org/10.5281/zenodo.277617

Tumanov, D. V. (2006). Five new species of the genus Milnesium (Tardigrada, Eutardigrada, Milnesiidae). Zootaxa, 1122, 1-23. https://doi.org/10.11646/zootaxa.1122.1.1

Vecchi, M., Cesari, M., Bertolani, R., Jönsson, K. I., Rebecchi, L., \& Guidetti, R. (2016). Integrative systematic studies on tardigrades from Antarctica identify new genera and new species within Macrobiotoidea and Echiniscoidea. Invertebrate Systematics, 30, 303-322. https://doi.org/10.1071/IS15033
Whiting, M. F., Carpenter, J. M., Wheeler, Q. D., \& Wheeler, W. C. (1997). The Strepsiptera problem: Phylogeny of the holometabolous insect orders inferred from $18 \mathrm{~S}$ and $28 \mathrm{~S}$ ribosomal DNA sequences and morphology. Systematic Biology, 46, 1-68. https://doi. org/10.1093/sysbio/46.1.1

Yamasaki, H., Fujimoto, S., \& Miyazaki, K. (2015). Phylogenetic position of Loricifera inferred from nearly complete $18 \mathrm{~S}$ and $28 \mathrm{~S}$ rRNA gene sequences. Zoological Letters, 1, 18-26. http://doi. org/10.1186/s40851-015-0017-0

\section{SUPPORTING INFORMATION}

Additional supporting information may be found online in the Supporting Information section at the end of the article.

\section{How to cite this article: Guil N, Jørgensen A,}

Kristensen R. An upgraded comprehensive multilocus phylogeny of the Tardigrada tree of life. Zool Scr. 2019;48:120-137. https://doi.org/10.1111/ zsc. 12321 